Neurolmages
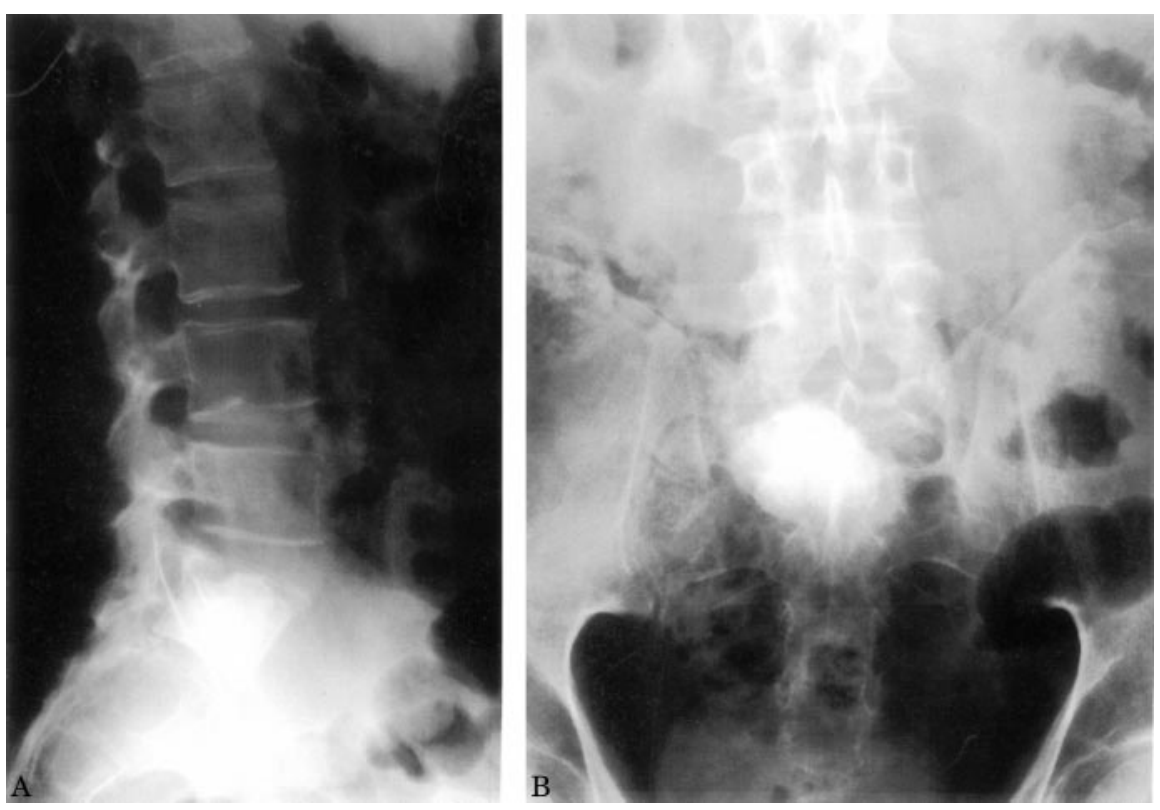

Figure. X-ray examination of the spine showed an isolated osteosclerotic focal bone lesion in the first sacral vertebra. (A) Lateral radiograph of the lumbar spine. (B) Anteroposterior view of the sacral bone.

\title{
CIDP and isolated osteosclerotic myeloma
}

J. Nickel, MD; E. Neuen-Jacob, MD; A. Saleh, MD;

N. Gattermann, MD; H.-P. Hartung, MD; and H. Köller, MD, Düsseldorf, Germany

A 44-year-old man developed a progressive severe tetraparesis and hypesthesia within 4 months due to chronic inflammatory demyelinating polyneuropathy (CIDP); a diagnosis reached through motor nerve conduction studies, CSF analysis, and sural

Address correspondence and requests for reprints to Dr. Hubertus Köller, Department of Neurology, Heinrich-Heine-University, PO Box 101007, D-40001 Düsseldorf, Germany; e-mail: koellerh@uni-duesseldorf.de

nerve biopsy. However, the patient did not respond to therapy with methylprednisolone, IV immunoglobulin, and plasma exchange. Biopsy of a mass lesion in the first sacral vertebra (figure) revealed an osteosclerotic myeloma with presence of lambda light chains, while a secreted monoclonal protein was not detectable on repeated serum and urine analyses. After local irradiation of the vertebra, the patient improved under further therapy with methylprednisolone; he regained the ability to walk within 1 year. Skeletal x-ray survey for an isolated myeloma ${ }^{1}$ should therefore be considered in patients with therapy-resistant CIDP.

1. Voss SD, Murphey, MD, Hall FM. Solitary osteosclerotic plasmacytoma: association with demyelinating polyneuropathy and amyloid deposition. Skeletal Radiol 2001;30:527-529. 


\section{Neurology}

\section{CIDP and isolated osteosclerotic myeloma}

J. Nickel, E. Neuen-Jacob, A. Saleh, et al.

Neurology 2004;63;2439

DOI 10.1212/01.WNL.0000141861.67742.68

\section{This information is current as of December 28, 2004}

\section{Updated Information \&} Services

References

Permissions \& Licensing

Reprints including high resolution figures, can be found at: http://n.neurology.org/content/63/12/2439.full

This article cites 1 articles, 0 of which you can access for free at: http://n.neurology.org/content/63/12/2439.full\#ref-list-1

Information about reproducing this article in parts (figures,tables) or in its entirety can be found online at:

http://www.neurology.org/about/about_the_journal\#permissions

Information about ordering reprints can be found online: http://n.neurology.org/subscribers/advertise

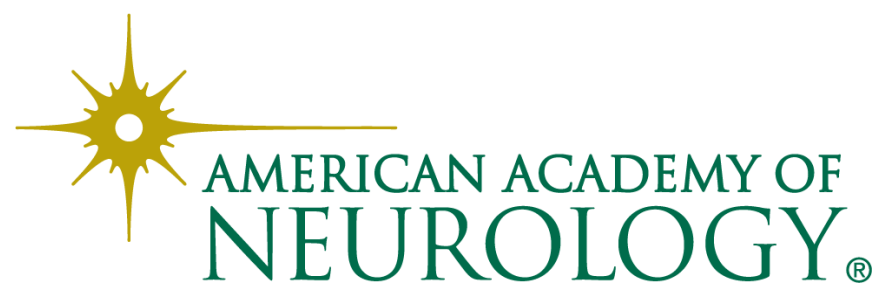

